\title{
Rich freshwater rotifer fauna of small lentic ecosystems of south Andaman, Andaman Sea, India (Rotifera: Eurotatoria)
}

\author{
B. K. ShaRMA ${ }^{1 *}$, C. RAGHUNATHAN ${ }^{2}$, S. SHARMA $^{1}$ \\ ${ }^{1}$ Bhushan Kumar Sharma \& Sumita Sharma, Freshwater Biology Laboratory, Department of Zoology, \\ North-Eastern Hill University, Shillong-793022, Meghalaya. E-mails: profbksharma@gmail.com*, \\ sharmasumita.nehu@gmail.com, *Corresponding author \\ ${ }^{2}$ Chelladurai Raghunathan, Andaman \& Nicobar Regional Station, Zoological Survey of India, Port Blair, \\ Andaman \& Nicobar. E-mail: raghuksc@ rediffmail.com
}

\begin{abstract}
Small lentic ecosystems are hypothesized to be interesting habitats for metazoan diversity. This study is undertaken to document Rotifera of small freshwater bodies of south Andaman, India. A total of 112 species (S), belonging to 32 genera and 19 families, recorded in our intensive February 2017 collections, indicate rich and diverse assemblage of the taxon. Total richness comprises $\sim 27 \%$ of the rotifer species known from India and thus affirms biodiversity interest and habitat diversity of the sampled habitats. This report adds 42 species, seven genera and three families to the taxa reported till date from freshwaters of the Andaman and Nicorbar islands. Rotifera meta-analysis indicates distinct increase in richness of Lecanidae > Brachionidae $>$ Trichocercidae and two-fold increase in Brachionus species. The biogeographically interesting elements comprise $8.0 \%$ of $\mathrm{S}$ and several species indicate regional distribution importance. The rotifer fauna shows high richness of cosmopolitan species ( $68 \%$ of S) and a number of tropical and subtropical species ( 22\% of S). The present study highlights distinct scope to augment Rotifera diversity of the Andaman and Nicorbar islands freshwaters vis-à-vis intensive sampling of varied habitats.
\end{abstract}

Keywords. Composition, insular freshwaters, new records, species richness.

\section{INTRODUCTION}

$\mathrm{R}$ otifera have been reported from inland freshwaters from distant parts of India since the first faunal survey of Anderson (1889) but these metazoans were firstly documented from insular freshwaters off the Indian mainland by Sharma (2017) based on samples from south Andaman collected during January 1990. Realizing the biodiversity importance of more investigations from insular waters, south Andaman freshwaters are revisited after a time period of 27 years to augment diversity of the taxon vis-à-vis our hypothesis on small lentic ecosystems as interesting rotifer habitats. The rich and diverse rotifer assemblages observed in this study merit interest for the diversity and distribution of the Indian Rotifera. An inventory of the examined species is presented, various new records are illustrated and remarks are made on composition, richness, new reports, interesting taxa. The results provide useful update for faunal analysis of the taxon off insular freshwaters of these islands located in the Andaman Sea.

\section{MATERIALS AND METHODS}

This study is based on analysis of samples collected, during February 2017, from about 40 freshwater ecosystems (Table 1) located between $11^{\circ}$ 30.619' $\mathrm{N}$ latitude and $92^{\circ} 43.432^{\prime} \mathrm{E}$ longitude of south Andamans, Andaman Sea, India (Fig. 1). The plankton and semi-planktonic samples were collected from varied small lentic freshwater bodies by towing a nylobolt plankton net (\#50 $\mu \mathrm{m}$ ) and were preserved in $5 \%$ formalin. All samples were screened, the rotifers were isolated and mounted in Polyvinyl alcohol-lactophenol, and observed with Leica (DM 1000) stereoscopic phase contrast 


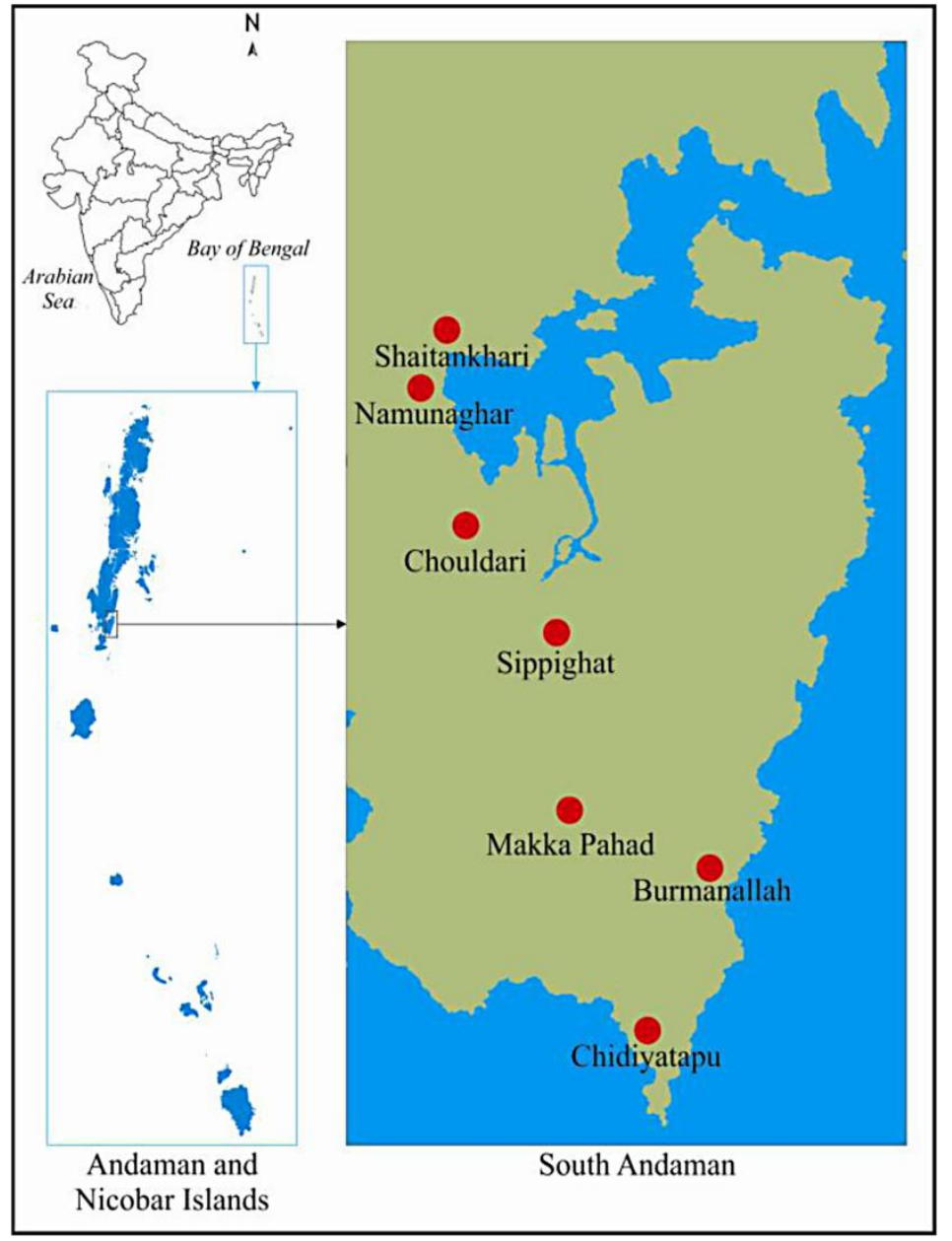

Figure 1. Map of India indicating the Andaman \& Nicobar Islands; map of the Andaman \& Nicobar Islands indicating south Andaman; map (part) of south Andaman indicating the sampled area (Google map).

microscope fitted with an image analyzer. The works of Koste (1978), Segers (1995), Sharma (1998), Sharma \& Sharma (1999, 2000, 2008) were followed for identification of the rotifer taxa. The micro-photographs of some interesting taxa are provided and measurements are indicated in micrometers $(\mu \mathrm{m})$.

\section{RESULTS}

Our collections from freshwaters of south Andaman revealed 112 species of Eurotatoria; a detailed systematic list of the recorded taxa is presented below:

\section{Phylum Rotifera \\ Class Eurotatoria \\ Subclass Monogononta \\ Order Ploima}

\section{Family Brachionidae}

1. Anuraeopsis coelata De Beauchamp, 1932 *

2. A. fissa (Gosse, 1851)

3. Brachionus angularis Gosse, 1851

4. B. bidentatus Anderson, 1889

5. B. calyciflorus Pallas, 1766

6. B. caudatus Barrois \& Daday, 1894 *

7. B. diversicornis (Daday, 1883) *

8. B. donneri Brehm, 1951* 
9. B. durgae Dhanapathi, $1974 *$

10. B. falcatus Zacharias, 1898

11. B. forficula Wierzejski, $1891 *$

12. B. quadridentatus Hermann, 1783

13. B. rubens Ehrenberg, 1838

14. B. urceolaris O.F. Muller, $1773 *$

15. Keratella tropica (Apstein, 1907)

16. Platyias leloupi (Gillard, 1967)*

17. Platyias quadricornis (Ehrenberg, 1832)

18. Plationus patulus (O.F. Müller, 1786)

\section{Family Epiphanidae}

19. Epiphanes brachionus (Ehrenberg, 1837)

\section{Family Euchlanidae}

20. Beauchampiella eudactylota (Gosse, 1886)

21. Euchlanis dilatata Ehrenberg, 1832

22. Dipleuchlanis propatula (Gosse, 1886)

23. Tripleuchlanis plicata (Levander, 1894)

\section{Family Mytilinidae}

24. Lophocharis salpina (Ehrenberg, 1834)* 25. Mytilina acanthophora Hauer, 1938

26. M. bisulcata (Lucks, 1912)

27. M. ventralis (Ehrenberg, 1830)

\section{Family Trichotriidae}

28. Macrochaetus collinsi (Gosse, 1867) *

29. Trichotria tetractis (Ehrenberg, 1830)

30. Wolga spinifera (Western, 1894) *

\section{Family Lepadellidae}

31. Colurella obtusa (Gosse, 1886)

32. C. uncinata (O.F. Müller, 1773)

33. Lepadella acuminata (Ehrenberg, 1834)

34. L. apsida Harring, 1916

35. L. biloba Hauer, 1938

36. L. costatoides Segers, 1992

37. Lepadella dactyliseta (Stenroos, 1898) *

38. L. discoidea Segers, 1993

39. L. ovalis (O. F. Müller, 1786)

40. L. patella (O.F. Muller, 1773)

41. L. rhomboides (Gosse, 1886)

42. L. triptera Ehrenberg, 1830

43. L. (Heterolepadella) apsicora Myers, 1934

44. L. (H.) ehrenbergi (Perty, 1850)

45. L. (H.) heterostyla (Murray, 1913)

\section{Family Lecanidae}

46. Lecane aculeata (Jakubski, 1912)
47. L. arcula Harring, 1914

48. L. batillifer (Murray, 1913)

49. L. bifurca (Bryce, 1892)*

50. L. bulla bulla (Gosse, 1851)

L. bulla diabolica (Hauer, 1936)

51. L. closterocerca (Schmarda, 1898)

52. L. curvicornis (Murray, 1913)

53. L. decipiens (Murray, 1913)*

54. L. doryssa Harring, 1914*

55. L. elegans Harring, 1914*

56. L. flexilis (Gosse, 1886)

57. L. furcata (Murray, 1913)

58. L. haliclysta Harring \& Myers, 1926*

59. L. hamata (Stokes, 1896)

60. L. hastata (Murray, 1913)*

61. L. hornemanni (Ehrenberg, 1834)*

62. L. inermis (Bryce, 1892)*

63. L. inopinata Harring \& Myers, 1926

64. L. lateralis Sharma, 1978

65. L. leontina (Turner, 1892)

66. L. ludwigii (Eckstein, 1883)*

67. L. luna (O.F .Müller, 1776)

68. L. lunaris (Ehrenberg, 1832)*

69. L. monostyla (Daday, 1897)

70. L. nana (Murray, 1913)*

71. L. nitida (Murray, 1913)

72. L. obtusa (Murray, 1913)*

73. L. papuana (Murray, 1913)

74. L. pusilla Harring, 1914*

75. L. pyriformis (Daday, 1905)*

76. L. quadridentata (Ehrenberg, 1830)

77. L. signifera (Jennings, 1896)

78. L. simonneae Segers, 1993*

79. L. stenroosi (Meissner, 1908)*

80. L. thienemanni (Hauer, 1938)

81. L. undulata Hauer, 1938*

82. L. unguitata (Fadeev, 1925)

83. L. ungulata (Gosse, 1887)

\section{Family Notommatidae}

84. Cephalodella gibba (Ehrenberg, 1830)*

85. C. mucronata Myers, 1924*

86. C. trigona (Rousselet, 1895)*

Family Scaridiidae

87. Scaridium longicaudum (O.F. Müller, 1786)

\section{Family Gastropodidae}

88. Ascomorpha ecaudis Perty, 1850*

\section{Family Trichocercidae}

89. Trichocerca bicristata (Gosse, 1887)*

90. T. bidens (Lucks, 1912)* 
91. T. cylindrica (Imhof, 1891)

92. T. flagellata Hauer, 1938

93. $T$ insignis (Herrick, 1885)*

94. T. longiseta (Schrank, 1802)

95. T. pusilla (Jennings, 1903)*

96. T. rattus (O.F. Müller, 1786)

97. T. ruttneri Donner, $1953^{*}$

98. T. similis (Wierzejski, 1893)

99. T. tigris (O.F. Müller, 1786)*

100. T. weberi (Jennings, 1903)

\section{Family Asplanchnidae}

101. Asplanchna brightwelli Gosse, 1850

\section{Family Synchaetidae}

102. Polyarthra vulgaris Carlin, 1943

\section{Order Flosculariaceae}

\section{Family Floscularidae}

103. Floscularia ringens (Linnaeus, 1758)

104. Sinantherina socialis (Linne, 1758)

105. S. spinosa (Thorpe, 1893)*

\section{Family Conochilidae}

106. Conochilus unicornis Rousselet, 1892

\section{Family Hexarthridae}

107. Hexarthra mira (Hudson, 1871)*

\section{Family Testudinellidae}

108. Pompholyx sulcata Hudson, 1885*

109. Testudinella patina (Hermann, 1783)

\section{Family Trochosphaeridae}

110. Filinia longiseta (Ehrenberg, 1834)

111. F. opoliensis (Zacharias, 1898)

\section{Sub-class Digononta}

\section{Order Bdelloidea}

\section{Family Philodinidae}

112. Rotaria neptunia (Ehrenberg, 1832)

*New records from Andaman \& Nicobar Islands

Forty-two species (marked*) are new records from Andaman and Nicobar islands while seven genera namely Ascomorpha, Cephalodella, Hexarthra, Lophocharis, Macrochaetus, Pompholyx and Wolga, and three Eurotatoria families i.e., Gastropodidae, Hexarthridae and Notommatidae are new additions. Brachionus donneri (Fig. 2A), B. durgae (Fig. 2B), Lecane batillifer, L. lateralis, L. simonneae (Fig. 2C), L. unguitata and Lepadella discoidea are elements of biogeographic interest. Ascomorpha ecaudis (Fig. 2D), Cephalodella trigona (Fig. 2E), Lecane bifurca, L. doryssa, L. elegans (Fig. 2F), L. haliclysta (Fig. 2G), L. hastata (Fig. 2H), L. hornemanni, L. nana, L. obtusa, L. pusilla (Fig. 2I), L. undulata, Lepadella dactyliseta, Lophocharis salpina, Platyias leloupi (Fig. 2J), Trichocerca bicristata, T. insignis, T. ruttneri (Fig. 2K), T. tigris and Wolga spinifera (Fig. 2L) are examples of regional distribution interest in India. Lecanidae (38 species) is the most diverse monogonont family; Brachionidae, Lepadellidae and Trichocercidae included 18, 15 and 12 species, respectively. Amongst diverse genera, Lecane indicated 38 species while Lepadella, Brachionus, and Trichocerca are represented by 13, 12 and 12 species, respectively.

\section{DISCUSSION}

One hundred and twelve species (S), belonging to 32 genera and 19 families of Eurotatoria, observed in our relatively intensive February 2017 collections from south Andaman, indicate rich and diverse Rotifera fauna. The richness comprises $27 \%$ of the rotifer species known from India (Sharma \& Sharma 2017) and thus deserves biodiversity interest, and affirms species-rich nature and habitat diversity of the sampled small lentic biotopes. Our report of 42 new species records from freshwaters of the Andaman and Nicorbar updates significantly the richness reported from these islands while seven genera and three families are added to the earlier list from south Andaman vide Sharma (2017). Though based on our limited collections, this update is attributed to intensive sampling of varied small wetlands.

Eurotatoria of biogeographic interest $(8.0 \%$ of S) reported include the Australasian Lecane batillifer; the Oriental Brachionus donneri and 
Lecane bulla diabolica; the cosmo (sub) tropical Brachionus durgae; the palaeotropical Lecane lateralis, L. simonneae, L. unguitata and Lepadella discoidea; and the palaearctic Cephalodella trigo$n a$. Of these, C. trigona is known from the Indian sub-region from lower Assam (Sharma et al. 2017); the present report of the Andaman freshwaters thus marked considerable extension of its distribution range. B. donneri and $L$. simonneae are known from this country from northeast India (NEI), Kerala and Tamil Nadu and B. durgae is characterized by its wider and disjunct distribution. In addition, this study re-affirmed the occurrence of $L$. batillifer and $L$. bulla diabolica from insular freshwaters of Andaman vide à report (Sharma 2017) based on the samples collected about 27 years earlier. Nevertheless, all species currently known from the Andaman freshwaters, except $C$. trigona, are reported from Southeast Asia particularly in the extensively studied Thai Rotifera (Sa-Ardrit et al. 2013).

Our collections indicated several species of regional distribution interest in the Indian sub-region namely Ascomorpha ecaudis, Lecane bifurca, $L$. doryssa, L. elegans, L. haliclysta, L. hastata, $L$. hornemanni, L. nana, L. obtusa, L. pusilla, L. undulata, Lepadella dactyliseta, Lophocharis salpina, Platyias leloupi, Trichocerca bicristata, T. insignis, T. ruttneri, T. tigris and Wolga spinifera. Amongst these, Lecane elegans, L. haliclysta and Trichocerca insignis are characterized by their distribution restricted to NEI (Sharma \& Sharma 2017) while Ascomorpha ecaudis, Lecane bifurca, L. doryssa, L. pusilla, L. undulata, Lepadella dactyliseta, Platyias leloupi, Trichocerca ruttneri, T. tigris and Wolga spinifera exhibit restricted distribution in this country. (Sharma \& Sharma loc. cit.). The reports of the stated species from south Andaman freshwaters merit biogeography interest for the Indian as well as south and Southeast Asian Rotifera.

Rotifera of the freshwaters of the Andamans is characterized by notable increase in the richness of Lecanidae > Brachionidae > Trichocercidae in contrast to 21, 12 and 6 species of three families reported earlier by Sharma (2017), respectively while Lepadellidae recorded only marginal increase. The notable two-fold increase of Brachionus species is, however, attributed to intensive sampling of limnetic waters of fish ponds while a majority of the sampled water bodies indicated the littoral-periphytic assemblages concurrent with their wetland character. Our collections indicate richness variations in different habitats and some wetlands record up to 30-40 species individually; the last feature corroborated with the reports from the small wetlands (dubies or dobas) of the Brahmaputra river basin (Sharma \& Sharma 2014). In general, Rotifera assemblages highlight importance of 'tropic centered' Lecane and Brachionus, indicate high number of cosmopolitan species ( $68 \%$ of $S$ ), and tropical and subtropical species together contribute $\sim 22 \%$ of S.

To sum up, this study affirms rich and diverse nature of Rotifera assemblage of our relatively extensive yet limited collections and it reiterates the role of small lentic freshwaters of south Andaman as rich habitats for the taxon. The rotifer fauna records considerable species update with notable increase in richness of Lecanidae > Brachionidae > Trichocercidae and notable two-fold increase in Brachionus spp. The study highlights more scope to augment Rotifera richness with extension of investigations to insular freshwaters of other parts of large group of the Andaman and Nicorbar islands, with emphasis on intensive sampling of varied habitats in general and small wetlands in particular.

Acknowledgements - The senior author is thankful to the Head, Department of Zoology, North-Eastern Hill University, Shillong for laboratory facilities. Two authors (BKS and SS) thank our co-author (CR) and the Officer-in-charge, Andaman \& Nicobar Regional Station, Zoological Survey of India, Port Blair, Andaman \& Nicobar for the facilities for field work, immense support and kind hospitality during our visit to south Andamans. We thank Dr. Tamal Mandal and Mr. Naveen Nigam of Andaman \& Nicobar Regional Station, Zoological Survey of India, Port Blair for their help in the field work. The authors have no conflict of interests. Finally, we thank our anonymous reviews for useful comments and suggestions. 
Table 1: List of the sampled localities of south Andaman

\begin{tabular}{|c|c|c|c|c|}
\hline Sl. No. & Date of collection & Locality & Latitude & Longitude \\
\hline 1. & \multirow[t]{8}{*}{07.02 .2017} & Sippighat & $11^{0} 34.463^{\prime} \mathrm{N}$ & $92^{0} 40.437^{\prime} \mathrm{E}$ \\
\hline 2. & & Sippighat & $11^{0} 34.469^{\prime} \mathrm{N}$ & $92^{0} 40.430^{\prime} \mathrm{E}$ \\
\hline 3. & & Sippighat & $11^{0} 34.576^{\prime} \mathrm{N}$ & $92^{0} 40.406^{\prime} \mathrm{E}$ \\
\hline 4. & & Sippighat & $11^{0} 35.519^{\prime} \mathrm{N}$ & $92^{0} 40.401^{\prime} \mathrm{E}$ \\
\hline 5. & & Sippighat & $11^{0} 35.515^{\prime} \mathrm{N}$ & $92^{0} 40.427^{\prime} \mathrm{E}$ \\
\hline 6. & & Sippighat & $11^{0} 35.640^{\prime} \mathrm{N}$ & $92^{0} 40.601^{\prime} \mathrm{E}$ \\
\hline 7. & & Sippighat & $11^{0} 36.187^{\prime} \mathrm{N}$ & $92^{0} 41.303^{\prime} \mathrm{E}$ \\
\hline 8. & & Sippighat & $11^{0} 36.266^{\prime} \mathrm{N}$ & $92^{0} 41.660^{\prime} \mathrm{E}$ \\
\hline 9. & \multirow[t]{17}{*}{08.02 .2017} & Chouldari & $11^{0} 36.906^{\prime} \mathrm{N}$ & $92^{0} 40.055^{\prime} \mathrm{E}$ \\
\hline 10. & & Chouldari & $11^{0} 36.719^{\prime} \mathrm{N}$ & $92^{0} 40.132^{\prime} \mathrm{E}$ \\
\hline 11. & & Chouldari & $11^{0} 36.809^{\prime} \mathrm{N}$ & $92^{0} 40.415^{\prime} \mathrm{E}$ \\
\hline 12. & & Chouldari & $11^{0} 36.819^{\prime} \mathrm{N}$ & $92^{0} 40.330^{\prime} \mathrm{E}$ \\
\hline 13. & & Chouldari & $11^{0} 37.019^{\prime} \mathrm{N}$ & $92^{0} 40.132^{\prime} \mathrm{E}$ \\
\hline 14. & & Chouldari & $11^{0} 37.005^{\prime} \mathrm{N}$ & $92^{0} 40.078^{\prime} \mathrm{E}$ \\
\hline 15. & & Chouldari & $11^{0} 37.119^{\prime} \mathrm{N}$ & $92^{0} 40.118 \mathrm{E}$ \\
\hline 16. & & Chouldari & $11^{0} 37.108^{\prime} \mathrm{N}$ & $92^{0} 40.204^{\prime} \mathrm{E}$ \\
\hline 17. & & Chouldari & $11^{0} 37.919^{\prime} \mathrm{N}$ & $92^{0} 40.324^{\prime} \mathrm{E}$ \\
\hline 18. & & Chouldari & $11^{0} 38.808^{\prime} \mathrm{N}$ & $92^{0} 40.002^{\prime} \mathrm{E}$ \\
\hline 19. & & Chouldari & $11^{0} 38.005^{\prime} \mathrm{N}$ & $92^{0} 39.889^{\prime} \mathrm{E}$ \\
\hline 20. & & Chouldari & $11^{0} 38.119^{\prime} \mathrm{N}$ & $92^{0} 39.902^{\prime} \mathrm{E}$ \\
\hline 21. & & Chouldari & $11^{\circ} 38.310^{\prime} \mathrm{N}$ & $92^{0} 39.926^{\prime} \mathrm{E}$ \\
\hline 22. & & Chouldari & $11^{0} 37.876^{\prime} \mathrm{N}$ & $92^{0} 39.941^{\prime} \mathrm{E}$ \\
\hline 23. & & Chouldari & $11^{0} 37.652^{\prime} \mathrm{N}$ & $92^{0} 39.832^{\prime} \mathrm{E}$ \\
\hline 24. & & Chouldari & $11^{0} 37.919^{\prime} \mathrm{N}$ & $92^{0} 39.711^{\prime} \mathrm{E}$ \\
\hline 25. & & Chouldari & $11^{0} 37.964^{\prime} \mathrm{N}$ & $92^{0} 39.889^{\prime} \mathrm{E}$ \\
\hline 26. & \multirow[t]{8}{*}{09.02 .2017} & Namunaghar & $11^{0} 40.280^{\prime} \mathrm{N}$ & $92^{0} 40.654^{\prime} \mathrm{E}$ \\
\hline 27. & & Namunaghar & $11^{0} 41.873^{\prime} \mathrm{N}$ & $92^{0} 40.773 \mathrm{E}$ \\
\hline 28. & & Shaitankhari & $11^{0} 41.658^{\prime} \mathrm{N}$ & $92^{0} 40.721^{\prime} \mathrm{E}$ \\
\hline 29. & & Shaitankhari & $11^{0} 41.534^{\prime} \mathrm{N}$ & $92^{0} 40.732^{\prime} \mathrm{E}$ \\
\hline 30. & & Shaitankhari & $11^{0} 42.703^{\prime} \mathrm{N}$ & $92^{0} 40.303^{\prime} \mathrm{E}$ \\
\hline 31. & & Shaitankhari & $11^{0} 42.849^{\prime} \mathrm{N}$ & $92^{0} 40.441^{\prime} \mathrm{E}$ \\
\hline 32. & & Shaitankhari & $11^{0} 43.049^{\prime} \mathrm{N}$ & $92^{0} 39.951^{\prime} \mathrm{E}$ \\
\hline 33. & & Shaitankhari & $11^{0} 43.164^{\prime} \mathrm{N}$ & $92^{0} 39.972^{/} \mathrm{E}$ \\
\hline 34. & \multirow[t]{3}{*}{10.02 .2017} & Chidiyatapu & $11^{0} 30.619^{\prime} \mathrm{N}$ & $92^{0} 42.411^{\prime} \mathrm{E}$ \\
\hline 35. & & Chidiyatapu & $11^{0} 30.631^{\prime} \mathrm{N}$ & $92^{0} 42.332^{\prime} \mathrm{E}$ \\
\hline 36. & & Chidiyatapu & $11^{0} 30.629^{\prime} \mathrm{N}$ & $92^{0} 41.499^{\prime} \mathrm{E}$ \\
\hline 37. & \multirow[t]{4}{*}{10.02 .2017} & Chidiyatapu & $11^{0} 30.688^{\prime} \mathrm{N}$ & $92^{0} 41.651^{\prime} \mathrm{E}$ \\
\hline 38. & & Burmahnallah & $11^{0} 33.652^{/} \mathrm{N}$ & $92^{0} 43.432^{\prime} \mathrm{E}$ \\
\hline 39. & & Burmahnallah & $11^{\circ} 33.617^{\prime} \mathrm{N}$ & $92^{0} 43.417^{\prime} \mathrm{E}$ \\
\hline 40. & & Makka Pahad & $11^{\circ} 34.418^{\prime} \mathrm{N}$ & $92^{0} 43.157^{\prime} \mathrm{E}$ \\
\hline
\end{tabular}




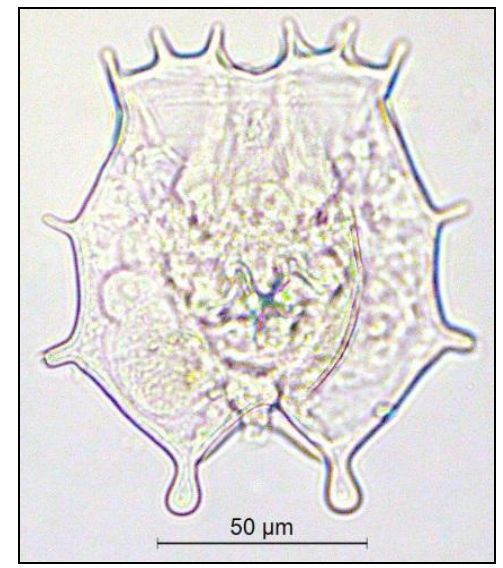

A

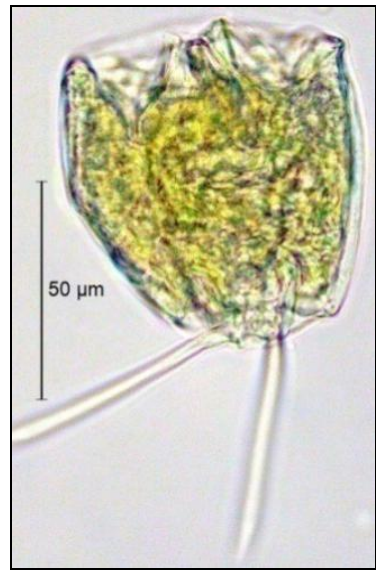

E

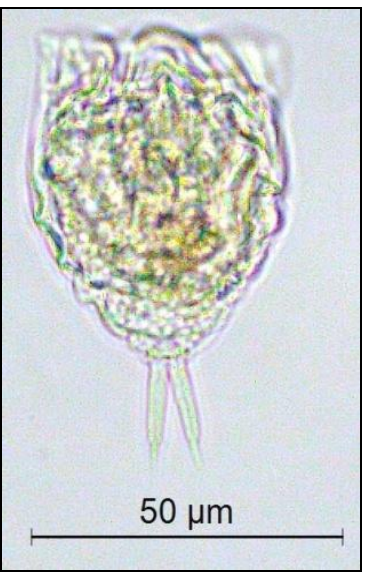

I

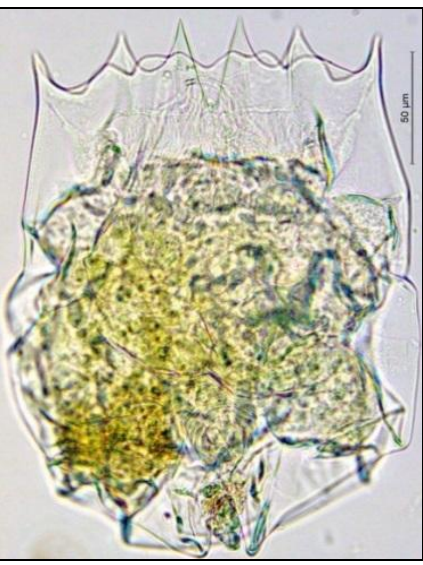

B

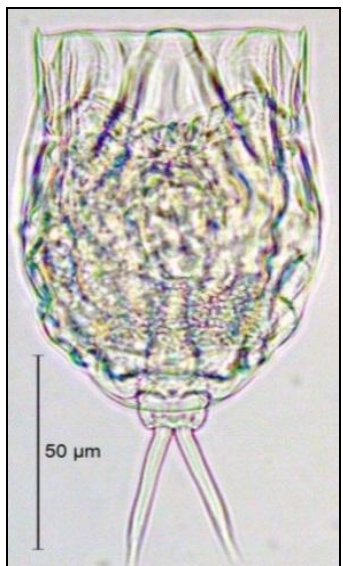

F

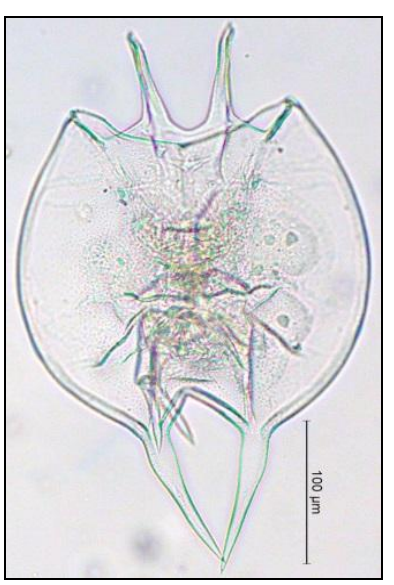

J

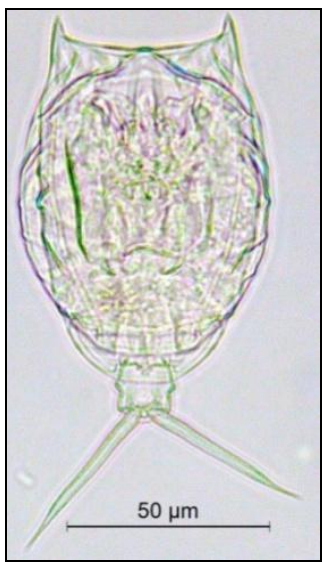

C

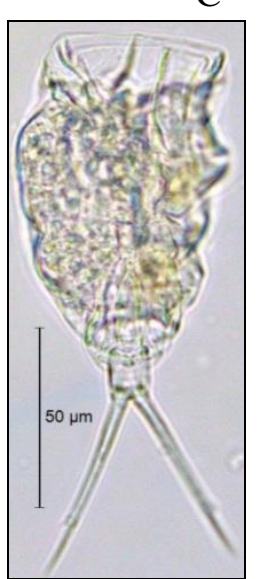

G

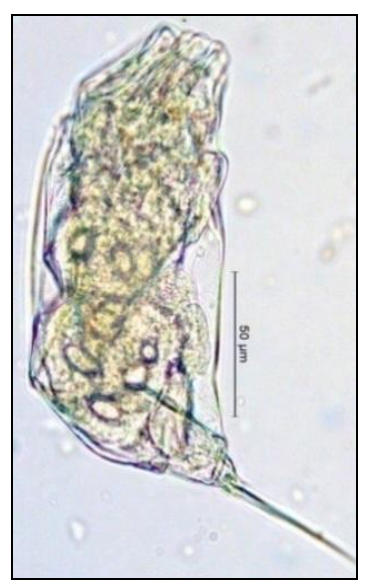

K

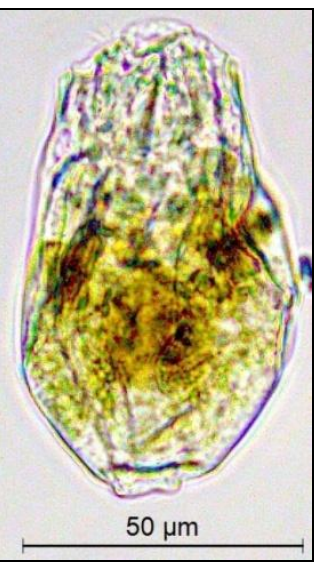

$\mathrm{D}$

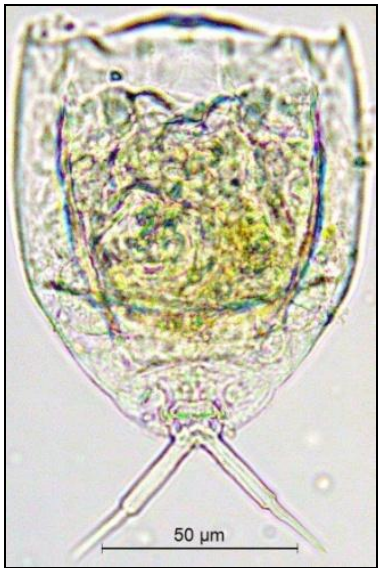

H

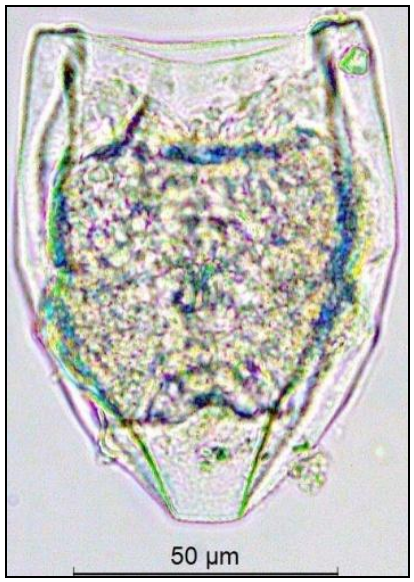

L

Figure 2. Interesting rotifer species: $\mathrm{A}=$ Brachionus donneri $\mathrm{Brehm}$, dorsal view; $\mathrm{B}=B$. durgae Dhanapathi, dorsal view; $\mathrm{C}=$ Le cane simonneae Segers, dorsal view; $\mathrm{D}=$ Ascomorpha ecaudis Perty, dorsal view; $\mathrm{E}=$ Cephalodella trigona (Rousselet), lateral view; $\mathrm{F}=$ Lecane haliclysta Harring \& Myers, ventral view; $\mathrm{G}=$ L. elegans Harring, dorsal view; $\mathrm{H}=$ L. hastata (Murray), ventral view; $\mathrm{J}=$ L. pusilla Harring, dorsal view; $\mathrm{I}=$ Platyias leloupi (Gillard), ventral view; $\mathrm{K}=$ Trichocerca ruttneri Donner, lateral view; $\mathrm{L}=$ Wolga spinifera (Western), ventral view. 


\section{REFERENCES}

ANDERSON, H.H. (1889): Notes on Indian Rotifera. Journal of the Asiatic Society of Bengal, 58: 45358.

Koste, W. (1978): Rotatoria. Die Rädertiere Mitteleuropas, begründet von Max Voigt. Überordnung Monogononta. Gebrüder Borntraeger, Berlin, Stuttgart. I. 673 pp., II. Tafelband. 234 pp.

SA-Ardrit, P., Pholpunthin, P. \& Segers, H. (2013): A checklist of the freshwater rotifer fauna of Thailand (Rotifera, Monogononta, Bdelloidea). Journal of Limnology, 72(2): 361-375. doi: $\underline{10.4081 / j \text { limnol.2013.s2.e18 }}$

SEGERS, H. (1995): Rotifera 2: Lecanidae. In. DUMONT, H.J. \& NOGRADY, T. (Eds.) Guides to identification of the Microinvertebrates of the Continental waters of the world, 6: 1-226. SPB Academic Publishing bv. Amsterdam, the Netherlands.

SHARMA, B.K. (1998): Freshwater rotifers (Rotifera: Eurotatoria). State Fauna Series: Fauna of West Bengal, Zoological Survey of India, Calcutta, 3(11): 341-461.

SHARMA, B.K. (2017): First report of freshwater Rotifers (Rotifera: Eurotatoria) from south Andaman, India: composition and interesting elements Journal of Asia-Pacific Biodiversity, 10: 261-266. doi: $\underline{10.1016 / j . j a p b .2017 .01 .003}$
SHARMA, B.K., KHAN, S.I. \& SHARMA, S. (2017): Biodiverse rotifer assemblage (Rotifera: Eurotatoria) of floodplain lakes of the Brahmaputra basin of lower Assam, northeast India: composition and ecosystem diversity. Chinese Journal of Oceanology and Limnology, doi: 10.1007/s00343-017-6251-X

SHARMA, B.K. \& SHARMA, S. (1999): Freshwater rotifers (Rotifera, Eurotatoria). Fauna of Meghalaya, State Fauna Series, 4(9): 11-161.

SHARMA, B.K. \& SHARMA, S. (2000): Freshwater rotifers (Rotifera, Eurotatoria). Fauna of Tripura, State Fauna Series, 7(4): 163-224

SHARMA, B.K. \& SHARMA, S. (2014): Northeast India - An important region with a rich biodiversity of Rotifera. In. B.K. SHARMA, H.J., DUMONT, R.L. WALLACE (Eds.) Rotifera XIII: Rotifer Biology-A structural and functional Approach. International Review of Hydrobiology, 99(1-2): 20-37. doi: 10.1002/iroh.201301701

SHARMA, B.K. \& SHARMA, S. (2017): Rotifera: Eurotatoria (Rotifers). In. CHANDRA, K., GOPI, K.C., RAO, D.V., VALARMATHI, K. \& ALFRED, J.R.B. (Eds.) Current status of freshwater faunal diversity in India, Zoological Survey of India, Kolkata, Chapter 7, p. 93-113.

SHARMA, S. \& SHARMA, B.K. (2008): Zooplankton diversity in floodplain lakes of Assam. Records of the Zoological Survey of India, Occasional Paper No. 290: 1-307. 